\title{
Pengembangan Modul Matematika Berbasis Active Learning untuk Memfasilitasi Kemampuan Berpikir Kreatif Matematis Siswa Sekolah Menengah Pertama
}

\author{
Andriadi $^{1}$, Depi Fitraini ${ }^{2}$, Suhandri ${ }^{3}$ \\ ${ }^{1,2,3}$ Program Studi Pendidikan Matematika, Fakultas Tarbiyah dan Keguruan, UIN Sultan Syarif Kasim Riau \\ Email: ${ }^{1}$ andriadi665@gmail.com, ${ }^{2}$ depi. fitraini@uin-suska. ac. id, ${ }^{3}$ suhandri@uin-suska. ac. id
}

\begin{abstract}
ABSTRAK. Penelitian ini bertujuan untuk mendeskripsikan modul matematika berbasis active learningyang valid dan praktis serta untuk mendeskripsikan kemampuan berpikir kreatif matematis siswa setelah menggunakan modul matematika berbasis active learning. Jenis penelitian ini merupakan penelitian pengembangan dengan menggunakan model ADDIE (Analysis, Design, Development, Implementation dan Evaluation). Penelitian ini dilakukan di Sekolah Menengah Pertama Negeri 16 Pekanbaru. Subjek penelitian ini adalah kelas VII SMP Negeri 16 Pekanbaru dan objek penelitian ini adalah modul matematika berbasis active learning. Jenis data penelitian ini adalah penelitian kualitatif dan kuantitatif. . Berdasarkan uji validitas,modul matematika berbasis active learningdinyatakan valid dengan persentase tingkat kevalidan 75,15\%. Berdasarkan uji praktikalitas, modul matematika berbasis active learning dinyatakan praktis dengan persentase tingkat kepraktisan 71,61\%. Dari hasil tersebut, mengidentifikasikan bahwa modul yang dikembangkan valid dan praktis. Berdasarkan tes kemampuan berpikir kreatif matematis siswa setelah menggunakan modul matematika berbasis active learning, kemampuan berpikir kreatif matematis siswa diperoleh persentase tingkat penguasaan yaitu $84,77 \%$ yang termasuk pada kategori tinggi.
\end{abstract}

Kata Kunci: Modul, Active Learning, Kemampuan Berpikir Kreatif Matematis,model ADDIE

\section{PENDAHULUAN}

Pembelajaran matematika merupakan suatu proses belajar mengajar yang dibangun oleh guru untuk mengembangkan kreatifitas berpikir siswa dalam meningkatkan kemampuan mengkontruksikan pengetahuan baru sebagai upaya meningkatkan penguasaan yang baik terhadap matematika. Untuk mengembangkan kreatifitas berpikir siswa pada dasarnya siswa harus mampu memecahkan masalah. Hal ini memerlukan kemampuan berpikir kritis dan kreatif. Kritis untuk menganalisis masalah dan kreatif untuk melahirkan alternatif pemecahan masalah. Pengembangan kemampuan berpikir kreatif serta memecahkan masalah yang berkaitan dengan siswa adalah sangat penting. Kreatifnya seorang siswa dapat melakukan pembelajaran secara bervariasi dan memiliki macam-macam kemungkinan menyelesaikan suatu persoalan. Berpikir kreatif salah satu tujuan penting dalam proses pembelajaran. Karena siswa yang kreatif akan mampu menemukan cara berbeda dalam menyelesaikan setiap permasalahan yang dihadapinya.

Meskipun memiliki kemampuan berpikir kritis dan kreatif sangat penting, pada kenyataannya kemampuan tersebut belum dikuasai dengan baik oleh siswa Indonesia. Hal tersebut dapat dilihat pada hasil The International Mathematic Sciency Study (TIMSS) tahun 2011 pada domain proses kognitif (konten) yang disajikan pada tabel 1 berikut.

Tabel 1. Persentase Rata-Rata Jawaban Benar Siswa Indonesia Dibandingkan Dengan Siswa Internasional Pada Domain Proses Kognitif Dalam Timss 2011

\begin{tabular}{|c|c|c|}
\hline \multirow{2}{*}{$\begin{array}{c}\text { Aspek pada Domain Proses } \\
\text { Kognitif }\end{array}$} & \multicolumn{2}{|c|}{ Rata-rata Jawaban Benar (\%) } \\
\hline & Indonesia & Internasional \\
\hline Pengetahuan & 31 & 49 \\
\hline Aplikasi & 23 & 39 \\
\hline Penalaran & 17 & 30 \\
\hline
\end{tabular}


Berdasarkan tabel 1 diatas, terlihat bahwa kemampuan siswa indonesia yang paling lemah pada domain proses kognitif adalah penalaran. Rata-rata jawaban benar pada kemampuan penalaran siswa indonesia hanya $17 \%$ atau 13\% lebih rendah dibandingkan rata-rata siswa Internasional. Selain itu, kemampuan penalaran siswa secara Internasional juga lebih lemah dibandingkan pengetahuan dan aplikasi. Adanya fakta hasil TIMSS 2011 pada domain proses kognitif bahwa kemampuan penalaran siswa yang masih lemah menjadi indikasi masih lemahnya kemampuan berpikir kritis dan kreatif. . Oleh karena itu, hasil TIMSS 2011 dapat dijadikan dasar bahwa kemampuan berpikir kritis dan kreatif siswa memerlukan perhatian khusus.

Menurut Nurina Happy dan Djamilah Bondan Widjajanti (2014), lemahnya kemampuan berpikir kreatif matematis siswa dapat disebabkan oleh beberapa faktor. Salah satu diantaranya adalah proses pembelajaran yang dilaksanakan. Pembelajaran matematika haruslah melibatkan siswa secara aktif serta memfasilitasi siswa untuk dapat menggunakan kemampuan berpikir kritis dan kreatifnya. Seperti yang diungkapkan oleh johnson bahwa jika siswa diberi kesempatan untuk melatih kemampuan berpikirnya, nantinya akan terbentuk suatu kebiasaan untuk dapat membedakan antara benar dan tidak benar, dugaan dan kenyataan, fakta dan opini, serta pengetahuan dan keyakinan. Dengan demikian siswa secara alami akan dapat membangun argumen yang didasari bukti logis dan terpercaya. Selain itu, siswa juga secara alami akan berpikir secara kreatif. Hal tersebut ditunjukkan dengan terbentuknya kebiasaan untuk membuat keterkaitan antara hal-hal yang berbeda, melihat kemungkinan yang tidak terduga, dan berpikir dengan cara baru pada masalah-masalah yang sudah bisa dihadapi. Oleh karena itu, sudah menjadi suatu kewajiban bagi guru untuk dapat merancang pembelajaran yang interaktif, inspiratif, menyenangkan, menantang, dan memotivasi siswa untuk berpartisipasi aktif.

Pembelajaran yang kurang memperhatikan perbedaan individual dan didasarkan pada keinginan guru, akan sulit untuk dapat mengantarkan anak didik ke arah pencapaian tujuan pembelajaran. Kondisi seperti inilah yang pada umumnya terjadi pada pembelajaran konvensional. Konsekuensi dari pendekatan pembelajaran seperti ini adalah terjadinya kesenjangan yang nyata antara anak yang cerdas dan anak yang kurang cerdas dalam pencapaian tujuan pembelajaran. Kondisi seperti ini mengakibatkan tidak diperolehnya ketuntasan dalam belajar, sehingga sistem belajar tuntas terabaikan. Hal ini membuktikan terjadinya kegagalan dalam proses pembelajaran di sekolah. Menyadari kenyataan seperti ini para ahli berupaya untuk mencari dan merumuskan strategi yang dapat merangkul semua perbedaan yang dimiliki oleh anak didik. Strategi pembelajaran yang ditawarkan adalah strategi belajar aktif (active learning strategy).

Berdasarkan kondisi yang telah diuraikan tersebut, maka perlu dicari solusi-solusi untuk mengatasinya. Untuk mengatasi masalah tersebut dapat dilakukan dengan berbagai cara. Peneliti menawarkan sistem pembelajaran dengan menggunakan modul. Modul yang akan peneliti kembangkan ini memiliki beberapa spesifikasi produk yang membedakannya dengan modul-modul biasa. Modul ini khusus dikembangkan dengan menggunakan strategi active learning yang diharapkan dapat menjadi solusi dari kurangnya bahan ajar dan dapat mengembangkan kemampuan berpikir kreatif siswa, sehingga mampu meningkatkan hasil belajar siswa. Modul adalah alat pembelajaran yang disusun sesuai dengan kebutuhan belajar pada pelajaran tertentu untuk keperluan proses pembelajaran tertentu.

Alasan pemilihan modul adalah karena guru telah maksimal mengajar dan menggunakan metode pembelajaran yang bervariasi,sehingga modul menjadi alternatif pembelajaran dan modul sangat mudah untuk dipelajari karena materi yang disajikan secara ringkas dan jelas, sehingga mudah dipelajari secara mandiri. Menurut Made Wena (2011) modul pembelajaran meliputi seperangkat aktivitas yang bertujuan mempermudah siswa mencapai seperangkat tujuan pembelajaran. Menurut Abdul Majid (2009)modul adalah sebuah buku yang ditulis dengan tujuan agar peserta didik dapat belajar secara mandiri tanpa atau bimbingan guru, sehingga modul berisi paling tidak tentang segala komponen dasar bahan ajar yang telah disebutkan sebelumnya. Melalui pembelajaran modul ini, diharapkan siswa mampu belajar lebih banyak, baik melalui bimbingan 
guru maupun belajar secara mandiri, sehingga siswa mampu membangun pengetahuannya sendiri, memecahkan soal-soal serta menyelesaikan tugas-tugas pembelajaran dengan benar. Untuk meningkatkan kemampuan dalam berpikir kreatif matematis, hendaklah siswa mampu dalam membangun pengetahuan yang dimilikinya. Siswa harus aktif mengkontruksi pengetahuan mereka. Sehingga siswa dituntut harus lebih aktif daripada guru, dengan demikian modul harus didesain dengan menggunakan strategi yang mengutamakan aktifitas siswa dalam membangun pengetahuannya serta dapat meningkatkan kemampuan berpikir kreatif, salah satunya adalah strategi active learning.

Pembelajaran dengan pendekatan active learningmerupakan salah satu pembelajaran yang berpusat pada siswa (student centered). Seperti kata Piagiet (Wina Sanjaya, 2006), pengetahuan itu akan bermakna manakala dicari dan ditemukan sendiri oleh siswa. Sehingga pendekatan ini menuntut siswa untuk lebih aktif menggunakan kemampuan berpikirnya sehingga akan meningkatkan kemampuan berpikir kreatifnya. Siswa mampu menyelesaikan masalah secara mandiri dan mendalam disertai argumen-argumen yang dapat dipertanggungjawabkan. Sehingga penerapan pendekatan berbasis active learning ini dirasa tepat dalam menunjang kemampuan berpikir kreatifmatematika siswa.

\section{TINJAUAN LITERATUR}

Abdul Majid (2009) mengatakan modul adalah sebuah buku yang ditulis dengan tujuan agar peserta didik dapat belajar secara mandiri tanpa atau bimbingan guru, sehingga modul berisi paling tidak tentang segala komponen dasar bahan ajar yang telah disebutkan sebelumnya. Modul dapat dirumuskan sebagai suatu unit yang lengkap yang berdiri sendiri dan terdiri atas suatu rangkaian kegiatan belajar yang disusun untuk membantu siswa mencapai sejumlah tujuan yang dirumuskan secara khusus dan jelas. Modul harus disajikan dengan menggunakan bahasa yang baik, menarik dan dilengkapi dengan ilustrasi.

Modul memiliki self contained, artinya dikemas dalam satu kesatuan yang utuh untuk mencapai kompetensi tertentu. Modul juga memiliki sifat membantu dan mendorong pembacanya untuk mampu membelajarkan diri sendiri dan tidak bergantung pada media lain. Modul yang dikembangkan adalah berbasis pembelajaran aktif. Warsono (2014) mengatakan pembelajaran aktif atau active learning secara sederhana didefenisikan sebagai metode pengajaran yang melibatkan siswa secara aktif dalam proses pembelajaran. Pembelajaran aktif mengkondisikan agar siswa selalu melakukan pengalaman belajar yang bermakna dan senantiasa berpikir tentang apa yang dapat dilakukannya selama pembelajaran. Menurut Pannen (Agus N cahyo, 2013), active learning merupakan suatu pendekatan dalam pengelolaan sistem melalui cara-cara belajar yang aktif menuju belajar yang mandiri. Menurut Agus N Cahyo (2013) belajar aktif merupakan strategi belajar yang diartikan sebagai proses belajar mengajar yang menggunakan berbagai metode yang menitikberatkan kepada keaktifan siswa dan melibatkan berbagai potensi siswa, baik yang bersifat fisik, mental, emosional maupun intelektual untuk mencapai tujuan pendidikan yang berhubungan dengan wawasan kognitif, afektif dan psikomotorik secara maksimal. Pembelajaran aktif (active learning) dimaksudkan untuk mengoptimalkan penggunaan semua potensi yang dimiliki oleh anak didik, sehingga semua anak didik dapat mencapai hasil belajar yang memuaskan sesuai dengan karakteristik pribadi yang mereka miliki.

Peran peserta didik dan guru dalam konteks belajar aktif menjadi sangat penting. Peran fungsional guru dalam pembelajaran aktif yang utama adalah sebagai sebagai fasilitator, yaitu seseorang yang membantu peserta didik untuk belajar dan memiliki keterampilan-keterampilan yang diperlukan dalam mencapai tujuan pembelajaran. Sebagai fasilitator, guru menyediakan fasilitas pedagogis, psikologis dan akademik bagi pengembangan dan pembangunan struktur kognitif siswanya. Beberapa ciri dari pembelajaran yang aktif sebagaimana yang dikemukan oleh Warsono (2014) dalam panduan pembelajaran model ALIS (Active Learning In School) adalah: a) 
Pembelajaran berpusat pada siswa. b) Pembelajaran terkait dengan kehidupan nyata. c) Pembelajaran yang mendorong anak untuk berpikir tingkat tinggi. d) Pembelajaran menyesuaikan gaya belajar anak yang berbeda-beda. e) Pembelajaran mendorong anak untuk berinteraksi multi arah (siswa-guru). f) Pembelajaran menggunakan lingkungan sebagai media atau sumber belajar. g) Penataan lingkungan belajar memudahkan siswa untuk melakukan kegiatan belajar. h) Guru memantau proses belajar siswa. , dan i) Guru memberikan umpan balikterhadap hasil kerja anak.

Ngalim Purwanto (2011) mengatakan berpikir adalah suatu keaktifan pribadi manusia yang mengakibatkan penemuan terarah kepada suatu tujuan. Berpikir melibatkan kegiatan memanipulasi dan mentransformasi informasi dalam memori. Kita berpikir untuk membentuk konsep, menalar, berpikir secara kritis, membuat keputusan, berpikir secara kreatif dan memecahkan masalah. Berpikir berguna untuk menemukan suatu pemahaman atau pengertian yang hendak dicari. Selain itu berpikir juga berguna dalam memecahkan masalah. Salah satu jenis berpikir yang digunakan untuk memecahkan masalah yaitu berpikir kreatif. Berpikir kreatif secara sederhana diartikan yaitu sebagai kemampuan menemukan cara yang berbeda dari yang biasanya. Menurut Conny Setiawan (Suryobroto, 2009) berfikir kreatif adalah suatu kemampuan untuk membentuk gagasan baru dan penerapan dalam penyelesaian masalah. Dari beberapa pendapat tentang pengertian berpikir kreatif dapat disimpulkan bahwa berpikir kreatif adalah suatu kemampuan menghasilkan ide atau gagasan baru terkait dengan kepekaan terhadap suatu masalah, mampu mempertimbangkan informasi baru dan ide-ide yang tidak biasanya dengan suatu pikiran terbuka, serta dapat melahirkan produk yang tidak terpikirkan oleh orang kebanyakan.

Orang disebut kreatif, karena dia mampu menemukan cara yang berbeda. Itulah yang disebut kreatif. Kreatif artinya berbeda. Isna Nur Lailatul Fauziyah(2013) mengatakan proses berpikir kreatif merupakan gambaran nyata dalam menjelaskan bagaimana kreativitas terjadi. Ditangan orang yang kreatif, benda yang pada mulanya biasa-biasa saja akan menjadi luar biasa, sesuatu yang tidak terpikirkan oleh orang kebanyakan akan terpikirkan olehnya. Walaupun bisa jadi, dia pun tidak merasakan sebelumnya. Seseorang yang kreatif harus memiliki motivasi, kebiasaan, dan kemampuan untuk menghasilkan dan memodifikasi sesuatu sehingga menjadi menarik atau memiliki nilai tambah. Biasanya anak yang berpikir kreatif selalu ingin tahu, memiliki minat yang luas, dan menyukai kegemaran dan aktivitas yang kreatif. Jadi dapat disimpulkan berpikir kreatif adalah kemampuan pemahaman, sensitivitas, dan apresiasinya melebihi kemungkinan rasional dari data dan pengetahuan yang dimilikinya.

Ali Hamzah dan Muhlisraini (2014)mengatakan matematika merupakan pengetahuan mengenal kuantiti dan ruang, salah satu cabang ilmu yang sistematis, teratur, dan eksak. Matematika merupakan angka-angka dan perhitungan yang merupakan bagian hidup manusia dimana dengannya dapat menolong manusia menafsirkan secara eksak berbagai ide-ide dan kesimpulan-kesimpulan. Ia berhubungan dengan logika dan problem-problem numerik, membahas fakta-fakta dan hubungannya, membahas problem ruang dan bentuk. Dalam pembelajaran sehari-hari kemampuan berpikir kreatif seorang siswa sangat diperlukan dalam belajar matematika. Hal ini karena sikap kreatif akan sangat mendorong tingkat penalaran siswa yang menjadi tujuan pengajaran matematika. Sikap kreatif diwujudkan dalam bentuk adanya suatu variasi cara siswa dalam belajar. Ketika siswa diberi tugas oleh gurunya, maka siswa yang kreatif akan memiliki banyak cara atau penyelesaian yang bermacam-macam. Sikap kreatif didukung oleh tidak mudah puas dengan apa yang telah diperoleh, tidak lekas putus asa. Jika dalam pembelajaran matematika, guru memberikan pertanyaan dan siswa memiliki jawaban yang diluar perkiraan, maka itulah indikator kreatif ada dalam diri siswa tersebut. Dari pembahasan mengenai berpikir kreatif matematis diatas dapat disimpulkan bahwa berpikir kreatif matematis adalah kemampuan menemukan dan menyelesaikan masalah matematika dengan banyak cara atau penyelesaian yang bermacam-macam serta tidak mudah puas dengan apa yang diperoleh, selalu ingin mengembangkan pemikiran dengan jawaban yang unik dan berbeda dari yang biasanya. 


\section{METODE}

Penelitian ini dilaksanakan di SMP Negeri 16 Pekanbaru yang beralamat di Jl. CempakaSukajadi Pekanbaru Riau pada semester ganjil tahun ajaran 2017-2018. Jenis penelitian yang dilakukan adalah metode penelitian dan pengembangan (Research and Development). Sugiyono (2013) mengatakan Research and Development adalah metode penelitian yang digunakan untuk menghasilkan produk tertentu dan menguji keefektifan produk tersebut. Untuk dapat menghasilkan produk tertentu digunakan penelitian yang bersifat analisis kebutuhan dan untuk menguji keefektifan produk tersebut supaya dapat berfungsi di masyarakat luas, maka diperlukan penelitian untuk menguji produk tersebut. Model penelitian yang digunakan adalah model ADDIE. Menurut Benni A. Pribadi (2010) salah satu model desain sistem pembelajaran yang memperlihatkan tahapan-tahapan dasar desain sistem pembelajaran yang sederhana dan mudah dipelajari adalah model ADDIE. Model ini, sesuai dengan namanya, terdiri dari lima fase atau tahap utama, yaitu (A)nalysis, (D)esign, (D)evelopment, (I)mplementation, dan (E)valuation. Menurut Endang Mulyatiningsih (2011) kelima fase atau tahap dalam model ADDIE, perlu dilakukan secara sistemik dan sistematik. Oleh sebab itu, model ini dapat digunakan untuk berbagai macam bentuk pengembangan produk seperti model, strategi pembelajaran, metode pembelajaran, media dan bahan ajar. Model ADDIE sudah diakui di dunia internasional di dalam media pendidikan sebagai sebuah kerangka berpikir sistemik yang baik.

Bagian terpenting dalam penelitian pengembangan yakni menguji cobakan produk kepada subjek uji coba dan penelitian. Hal ini dilakukan untuk mendeskripsikan kevalidan, kepraktisan dan keefektifan dari modul yang dikembangkan. Uji coba ini dilakukan setelah produk dinyatakan valid oleh validator atau ahli aspek teknologi dan validator atau ahli aspek materi, setelah terpenuhi keduanya baru produk tersebut diuji cobakan kepada subjek penelitian. Peneliti hanya menguji sampai pada tahap pengujian terbatas dikarenakan adanya keterbatasan waktu, dana dan tenaga dari peneliti sendiri. Pada tahap pengujian terbatas, peneliti menggunakan uji coba kelompok kecil, kemudian dilanjutkan dengan uji coba kelompok besar, atau dengan menggunakan Posttest only Control Group Design. Uji coba kelompok kecil digunakan untuk menguji tingkat validitas instrumen tes. Sedangkan uji coba kelompok besar digunakan untuk mengetahui lebih lanjut tingkat efektifitas produk melalui instrumen tes yang sudah teruji validitas pada uji coba kelompok kecil. Desain Posttest only Control Design menurut Yulius Slamet (2008). Subjek penelitian untuk uji validitas produk adalah ahli materi dan ahli teknologi. Sedangkan subjek untuk uji efektifitas produk adalah siswa Sekolah Menengah Pertama (SMP) 16 Pekanbaru kelas VII. Subjek uji coba diambil dari uji homogenitas yang diperoleh dari nilai ulangan harian. Setelah homogen digunakan teknik simple random samplinguntuk menentukan kelas eksperimen dan kelas kontrol. Sebelum dilakukan uji coba produk modul kepada kelas eksperimen dan kelas kontrol tersebut, peneliti terlebih dahulu menguji cobakan produk modul kepada 6 siswa dari kelas lain sebagai uji coba kelompok kecil. Jenis data penelitian ini adalah data kualitatif dan kuantitatif. Data kualitatif berupa hasil dari lembar validasi ahli teknologi pendidikan dan ahli materi pembelajaran serta angket respon siswa. Data kuantitatif bersumber dari evaluasi belajar yang dicapai siswa berdasarkan kemampuan matematisnya (kemampuan berpikir kreatif). Data-data yang diperoleh peneliti dengan menggunakan beberapa teknik, antara lain teknik angket dan tes.

\section{HASIL}

Penelitian ini terdiri dari lima tahapan yaitu tahap analisis, tahap perancangan (design), tahap Development, tahap pelaksanaan (Implementation) dan tahap evaluasi(Evaluation). Tahap analisis terdiri dari analisis kinerja dan analisis kebutuhan. Analisis Kinerja dilakukan dengan merinci isi materi ajar dalam bentuk garis besar. Analisis ini mencakupanalisis struktur isi dan analisis konsep. Modul ini berisi beberapa materi yang berkaitan dengan himpunan berdasarkan masalah yang dalam kehidupan sehari-hari dan langkah-langkah penyelesaiannya. Materi disajikan menjadi 
empat kegiatan belajar sebagai berikut: a) Kegiatan Belajar 1: Memahami pengertian dan notasi himpunan, serta penyajiannya, b) Kegiatan belajar 2 : Memahami konsep himpunan kosong, semesta dan bagian, 3) Kegiatan belajar 3: Memahami diagram venn dan operasi pada himpunan, dan 4) Kegiatan belajar 4 : Menyelesaikan masalah dengan menggunakan konsep himpunan.

Pada tahap perancangan penulis merancang kisi-kisi instrumen penelitian berupa angket penilaian modul dan modul tersebut. Kemudian merancang pembuatan modul matematika berbasis active learningserta komponen-komponen yang berkaitan dengan modul tersebut. Setelah selesai pembuatan desain modul, kemudian modul yang dikembangkan divalidasi oleh validator ahli materi pembelajaran dan ahli teknologi pendidikan dengan menggunakan angket. Angket yang digunakan telah divalidasi oleh validator ahli instrumen menggunakan lembar validasi angket. Setelah angket penilaian sudah valid, kemudian angket tersebut digunakan untuk memvalidasi modul yang dikembangkan. Validasi ini bertujuan untuk melihat apakah modul yang dibuat sudah layak atau tidak untuk diujicobakan. Tahap implementasi dilakukan dengan uji coba modul terhadap kelompok kecil, uji coba modul terhadap kelompok terbatas dan post-test untuk kemampuan berpikir kreatif matematika pada kelompok terbatas. Uji coba kelompok kecil dengan jumlah responden 6 orang siswa. Uji coba kelompok terbatas dilaksanakan di kelas VII SMP Negeri 16 Pekanbaru.

Tahap evaluasi dilakukan setelah melakukan validasi dan uji coba lapangan. Modul matematika berbasis active learning sudah dinyatakan valid oleh Ahli materi pembelajaran dan juga dikatakan valid oleh Ahli teknologi pendidikan. Kemudian, pada tahap uji coba diperoleh hasil sangat praktis dalam penggunaannya. Namun saran-saran yang diberikan oleh Validator dijadikan sebagai bahan pertimbangan dalam penyempurnaan modul matematika berbasis active learning.

\section{PEMBAHASAN}

Modul berbasis active learning bertujuan membantu siswa untuk menemukan konsep, membantu siswa dalam menerapkan dan mengintegrasikan berbagai konsep matematika secara kreatif serta memperkuat pendalaman dan penerapan materi pembelajaran. Pembelajaran dengan menggunakan modul berbasis active learning akan menghasilkan pembelajaran yang bermakna jika dapat berjalan dan diikuti dengan baik oleh siswa, karena pembelajaran dengan menggunakan modul berbasis active learning lebih menekankan aktif siswa daripada guru. Setiap tahap kegiatan siswa terlibat secara aktif baik intelektual maupun emosional. Dalam pembelajaran menggunakan modul berbasis active learning ini siswa berinteraksi langsung dengan sumber belajar, siswa mengkonstruksi sendiri pengetahuannya dengan didampingi oleh modul dan siswa dituntut harus mampu bekerja sama serta menghargai orang lain dalam kelompoknya, sehingga pembelajaran akan meningkatkan kualitas berpikir siswa. Adapun hal-hal yang harus diperhatikan dalam mengimplementasikan pembelajaran dengan menggunakan modul berbasis active learning yaitu: pembelajaran berpusat pada anak didik, penekanan pada penemuan pengetahuan, sangat menyenangkan, memberdayakan semua indera dan potensi anak didik, menggunakan banyak metode, menggunakan banyak media, disesuaikan dengan pengetahuan yang sudah ada. penelitian ini terdiri dari 6 tahapan yaitu:

1. Tahap Analisis

Analisis Kinerja dilakukan dengan merinci isi materi ajar dalam bentuk garis besar. Analisis ini mencakup Analisis Struktur Isi, Analisis Konsep. Modul ini berisi beberapa materi yang berkaitan dengan himpunan berdasarkan masalah yang dalam kehidupan sehari-hari dan langkah-langkah penyelesaiannya. Peneliti melakukan wawancara dengan salah satu guru matematika SMP Negeri 16 Pekanbaru mengenai bahan pembelajaran dan kemampuan siswa dalam proses pembelajaran. Berdasarkan hasil wawancara yang dilakukan peneliti dengan salah satu guru matematika SMP Negeri 16 Pekanbaru, dapat disimpulkan bahwa pelaksanaan proses pembelajaran siswa lebih mengarah untuk menyelesaikan soal-soal rutin dengan menggunakan rumus yang telah disajikan 
pada buku paket dan modul. Rumus-rumus yang disajikan tersebut akan membuat siswa cenderung untuk menghafal rumus dalam menyelesaikan soal rutin dan hanya terfokus pada satu jawaban yang benar saja tanpa membuktikannya kembali kebenarannya. Oleh karena itu, diperlukan suatu bahan ajar dalam pembelajaran yang dapat membantu siswa dalam menemukan penyelesaian sendiri untuk memecahkan suatu soal tidak rutin dengan strateginya sendiri dan bimbingan guru. Tanpa harus menghafal rumus dan tidak terfokus pada satu jawaban benar saja sehingga siswa dapat menyelesaikan soal dengan baik dan memfasilitasi kemampuan berpikir kreatif matematis siswa.

\section{Tahap Perancangan (Design)}

Pada tahap perancangan penulis merancang kisi-kisi instrumen penelitian berupa angket penilaian modul dan modul tersebut. Kemudian merancang pembuatan modul matematika berbasis active learningserta komponen-komponen yang berkaitan dengan modul tersebut seperti cover, peta konsep dan kegiatan belajar.

\section{Tahap Development}

Setelah selesai pembuatan desain modul, kemudian modul yang dikembangkan divalidasi oleh dua validator ahli materi pembelajaran dan satu ahli teknologi pendidikan dengan menggunakan angket. Angket yang digunakan telah divalidasi oleh validator ahli instrumen menggunakan lembar validasi angket. Setelah angket penilaian sudah valid, kemudian angket tersebut digunakan untuk memvalidasi modul yang dikembangkan. Validasi ini bertujuan untuk melihat apakah modul yang dibuat sudah layak atau tidak untuk diujicobakan. Validasi modul berbasis pendekatan active learning dilakukan dengan cara menghadirkan ahli materi pembelajaran dan ahli media pembelajaran. Hal ini dilakukan agar modul yang dikembangkan dapat dinilai serta diberi saran perbaikan untuk direvisi sehingga terciptalah modul yang baik. Berikut ini disajikan hasil penilaian dan tanggapan dari ahli materi pembelajaran dan ahli media pembelajaran dari instansi UIN SUSKA RIAU dan SMP Negeri 16 Pekanbaru. Hasil validasi oleh ahli materi pembelajaran terangkum pada tabel II.

Tabel 2. Validasi Ahli Materi terhadap Modul Matematika Berbasis Active Learning

\begin{tabular}{llll}
\hline No. & VariabelValiditasModul & Nilai validasi & Kriteria \\
\hline 1 & Syarat Didaktik & $73,33 \%$ & Valid \\
2 & SyaratAspekKualitasMateri & $80 \%$ & Valid \\
3 & Syarat Active Learning dan Berpikir Kreatif & $81,33 \%$ & Sangat Valid \\
\hline \multicolumn{2}{l}{ Rata-rata } & $79,09 \%$ & Valid \\
\hline
\end{tabular}

Berdasarkan tabel II tersebut, jelas terlihat bahwa persentase keseluruhan dari penilaian kedua ahli materi pembelajaran adalah valid dengan persentase $79,09 \%$ karena berada pada rentang presentase $61 \%$ sampai $80 \%$, sehingga modul pembelajaran tidak memerlukan revisi. Namun komentar dan saran dari ahli materi pembelajaran dijadikan bahan perbaikan untuk menyempurnakan modul pembelajaran. Sedangkan untuk hasil validasi oleh ahli teknologi pendidikan dapat dilihat pada tabel III berikut:

\section{Tabel III. Hasil Validasi AhliTeknologi terhadap Modul Matematika Berbasis Active Learning}

\begin{tabular}{|l|l|l|l|}
\hline No. & VariabelValiditas Modul & Nilai Validasi & Kriteria \\
\hline 1 & Aspek Konstruksi & $75,75 \%$ & Valid \\
\hline 2 & Aspek Teknis & 66,76 & Valid \\
\hline Rata-rata & $71,21 \%$ & Valid \\
\hline
\end{tabular}

Berdasarkan tabel III di atas, jelas terlihat bahwa persentase nilai validitas keseluruhan dari penilaian oleh kedua ahli media pembelajaran adalah valid, karena berada pada rentang $61 \%$ sampai $80 \%$, sehingga modul pembelajaran tidak memerlukan revisi. Namun komentar dan saran dari ahli teknologi pendidikan dijadikan bahan perbaikan untuk menyempurnakan modul 
pembelajaran. Untuk melihat hasil penilaian validitas secara keseluruhan maka penilaian dari ahli materi pembelajaran dan ahli teknologi pendidikan dijumlahkan dan dibagi dua seperti tampak pada tabel IV berikut.

Tabel IV. Perhitungan Data Hasil Uji ValiditasSecara Keseluruhan

\begin{tabular}{|c|c|c|}
\hline & Variabel & \\
\hline No. & ValiditasModul & Persentasi keidealan \\
\hline 1 & Ahli Teknologi Pendidikan & $71,21 \%$ \\
\hline 2 & $\begin{array}{l}\text { Ahli Materi Pembelajaran } \\
\text { Rata-rata }\end{array}$ & $\begin{array}{c}79,09 \% \\
\mathbf{7 5 , 1 5 \%} \text { (valid) }\end{array}$ \\
\hline
\end{tabular}

Berdasarkan perhitungan diatas, jelas terlihat bahwa persentase keseluruhan dari penilaian para ahli materi pembelajaran dan ahli teknologi pendidikan dengan persentase $75,15 \% \%$ adalah valid, karena berada pada rentang 61\% sampai $80 \%$, sehingga modul pembelajaran sudah layak untuk digunakan. Namun saran dan komentar dari ahli dijadikan bahan perbaikan dalam penyempurnaan modul ini.

\section{Tahap Pelaksanaan (Implementation)}

Tahap implementasi dilakukan dengan uji coba modul terhadap kelompok kecil, uji coba modul terhadap kelompok terbatas dan post-test untuk kemampuan berpikir kreatif matematika pada kelompok terbatas. Uji coba kelompok kecil dengan jumlah responden 6 orang siswa. Uji coba kelompok terbatas dilaksanakan di kelas VII SMP Negeri 16 Pekanbaru. Setelah modul divalidasi dan direvisi berdasarkan saran dari ahli materi pembelajaran dan teknologi pendidikan, kemudian modul diuji cobakan pada kelompok kecil melalui angket praktikalitas modul. Peneliti melakukan uji coba kelompok kecil dengan jumlah responden 6 siswa. Uji coba kelompok kecil dilakukan untuk melihat apakah di dalam modul masih ditemukan kesalahan dan kekurangan yang ditemukan oleh siswa. Adapun penilaian modul matematika berbasis active learning pada tabel V.

Tabel V. Persentase Praktikalitas Uji Coba Modul Kelompok Kecil

\begin{tabular}{|c|c|c|c|}
\hline \multirow[b]{2}{*}{ No. } & \multirow[b]{2}{*}{ Variabel Praktikalitas Modul } & Nilai & \multirow[b]{2}{*}{ Kriteria } \\
\hline & & Praktikalitas & \\
\hline 1 & Minat siswa dan tampilan modul & $80,33 \%$ & Praktis \\
\hline 2 & Proses penggunaan & $65,83 \%$ & Praktis \\
\hline 3 & Pemahaman dan materi & $77,33 \%$ & Praktis \\
\hline 4 & Waktu & $60 \%$ & Cukup Praktis \\
\hline 5 & Evaluasi & $71,67 \%$ & Praktis \\
\hline \multicolumn{2}{|c|}{ Rata-rata } & $75,30 \%$ & Praktis \\
\hline
\end{tabular}

Berdasarkan hasil perhitungan pada tabel Vterlihat bahwa persentase tingkat kepraktisan pada uji coba kelompok kecil75,30\% adalah praktis, karena berada pada rentang $61 \%$ sampai 80\%, sehingga modul tidak memerlukan revisi. Namun saran perbaikan dari siswa dijadikan bahan perbaikan dalam penyempurnaan modul.

Setelah modul direvisi berdasarkan saran perbaikan dari kelompok kecil, kemudian modul diuji cobakan pada kelompok terbatas melalui angket praktikalitas modul. Peneliti melakukan uji coba modul kelompok terbatas terhadap siswa kelas VII SMP 16 Pekanbaru. Adapun penilaian modul dapat dilihat pada tabel VI berikut:

Tabel VI. Persentase Praktikalitas Uji Coba Modul Kelompok Terbatas

\begin{tabular}{cccc}
\hline No. & VariabelValiditasModul & Nilai Praktikalitas & Kriteria \\
\hline 1 & MinatSiswadanTampilanModul & $70,58 \%$ & Praktis \\
2 & Proses Penggunaan & $71,12 \%$ & Praktis \\
3 & Pemahaman danMateri & $73,03 \%$ & Praktis \\
4 & Waktu & $58,04 \%$ & Cukup Praktis \\
5 & Evaluasi & $73,54 \%$ & Praktis \\
\hline & Rata-rata & $71,61 \%$ & Praktis \\
\hline
\end{tabular}


Berdasarkan hasil perhitungan pada tabel VI terlihat bahwa persentase tingkat kepraktisan pada uji coba kelompok terbatas $71,61 \%$ adalah praktis, karena berada pada rentang $61 \%$ sampai $80 \%$, sehingga modul tidak memerlukan revisi. Namun saran perbaikan dari siswa dijadikan bahan perbaikan dalam penyempurnaan modul.

\section{Tahap Evaluasi(Evaluation)}

Tahap evaluasi dilakukan setelah melakukan validasi dan uji coba lapangan. Modul matematika berbasis active learning sudah dinyatakan valid oleh Ahli materi pembelajaran dan juga dikatakan valid oleh Ahli teknologi pendidikan. Kemudian, pada tahap uji coba diperoleh hasil sangat praktis dalam penggunaannya. Namun saran-saran yang diberikan oleh Validator dijadikan sebagai bahan pertimbangan dalam penyempurnaan modul matematika berbasis active learning. Peneliti telah melaksanakan evaluasi terhadap modul matematika berbasis active learning sesuai dengan saran dari tim ahli serta siswa. Peneliti melakukan analisis aspek efektifitas modul berbasis Active Learningdengan membandingkan skor posttest kelas eksperimen dan kelas kontrol. Sebelum diuji perbedaan data skor posttest kelas eksperimen dengan kelas kontrol, perlu diuji normalitas dan homogenitasnya dan kemampuan terlebih dahulu menggunakan skor ulangan harian pada kelas eksperimen dan kelas kontrol. Dari data skor ulangan hariandapat disimpulkan bahwa kedua kelas tersebut homogen. Dengan menggunakan pengambilan sampel teknik Simple Random Sampling diperoleh kelas VII. 2 sebagai kelas eksperimen dan VII. 4 sebagai kelas kontrol. Setelah diketahui kelas eksperimen dan kelas kontrol tersebut telah homogen baru kita dapat memberikan perlakuan Hasil uji normalitas data skorposttest, diperoleh $x^{2}$ hitung kelas eksperimen sebesar 1,680 dan $x^{2}$ tabel sebesar 11,070. Untuk $x^{2}$ hitung kelas kontrol sebesar 3,899 dan $x^{2}$ tabel sebesar 11,070. Dengan demikian $x^{2}$ hitung $<x^{2}$ tabel, maka dapat dikatakan bahwa data berasal dari populasi yang berdistribusi normal. Setelah data berdistribusi normal dilanjutkan dengan uji homogenitas. Berdasarkan hasil uji homogenitas diperoleh $\mathrm{F}_{\text {hitung }}$ sebesar 1,774 dan $\mathrm{F}_{\text {tabel }}$ sebesar 1,860.

Dengan demikian maka $\mathrm{F}_{\text {hitung }}<\mathrm{F}_{\text {tabel }}$, maka varians data skor posttestkelas VII. 4 dan kelas VII. 1adalah homogen. Setelah dilakukan uji normalitas dan uji homogenitas, data posttesthasil penelitian mempunyai sebaran yang normal dan homogen. Karena data posttest normal dan homogen, maka uji perbedaan menggunakan test $\mathrm{t}$. Dari Hasil uji t posttest kemampuan berpikir kreatif matematika siswa diperoleh $t_{\text {hitung }}$ sebesar 4,057 dan $t_{\text {tabel }}$ sebesar 2,00. Dengan demikian $t_{\text {hitung }}>t_{\text {tabel }}$, artinya terdapat perbedaan kemampuan berpikir kreatif matematika antara kelas VII. 4 sebagai kelas eksperimen yang menerapkan metode Active Learningdan kelas VII. 1 sebagai kelas kontrol yang menerapkan pembelajaran konvensional.

Hasil analisis data menunjukkan bahwa modul matematika berbasisactive learning yang dihasilkan dikategorikan valid dengan nilai validitas adalah 79,09\%. Hal ini menunjukkan Modul berbasis active learning yang dihasilkan telah teruji dan dinyatakan valid oleh validator sehingga sudah bisa dijadikan sebagai bahan ajar.

Modul berbasis active learning diberikan kepada 6 siswa untuk dilakukan uji praktikalitas kelompok kecil guna mengetahui tingkat kepraktisan modul yang dikembangkan. Hasil analisis uji praktikalitas modul kelompok kecil oleh 6 siswa dinyatakan kategori praktis dengan persentase tingkat kepraktisan yaitu 75,30\%. Modul berbasis active learning diberikan kepada 30 orang siswa kelas VII. 4 di SMP Negeri 16 Pekanbaru untuk dilakukan uji praktikalitas guna mengetahui tingkat kepraktisan modul yang dikembangkan. Hasil analisis uji praktikalitas modul oleh siswa dinyatakan kategori praktis yaitu 71,61\%. Ini berarti secara keseluruhan modul ini diminati karena memudahkan siswa untuk mengerti materi himpunan serta praktis digunakan sebagai bahan ajar. Siswa merasa tertarik menggunakan Modul berbasis active learning karena penyampaian materinya disampaikan secara kreatif dan inovatif. Modul matematika juga sangat menarik karena di dalamnya diberikan gambar, warna yang dapat memotivasi siswa untuk rajin belajar. 
Setelah siswa diberikan pembelajaran dengan menggunakan modulmatematika berbasis active learning, maka diakhir pembelajaran siswa diberikan posttest guna mengetahui keefektifan modul yang dikembangkan terhadap berpikir kreatif matematika siswa. Berdasarkan hasil analisis data tes berpikir kreatif siswa diperoleh bahwa sebelum diberikan modul yang dikembangkan masing-masing telah didapatkan bahwa kelas eksperimen dan kelas kontrol mempunyai data yang homogen dan normal serta tidak terdapat perbedaan yang signifikan pada kemampuan berpikir kreatif siswa yang didapat dari hasil ulangan harian siswa. Lalu dilanjutkan dengan penelitian dimana kelas eksperimen diberikan modul matematika berbasis active learningsedangkan kelas kontrol hanya pembelajaran konvensional saja. Setelah proses pembelajaran selesai, dilakukan tes kembali dengan memberikan siswa pada kelas eksperimen dan kelas kontrol soal posttestalu diuji kembali. Didapatkan hasil bahwa kelas tersebut masih mempunyai hasil data yang normal dan homogen namun diketahui bahwa terdapat perbedaan yang signifikan pada kemampuan berpikir kreatif siswa. Berdasarkan data tersebut dapat disimpulkan bahwa modul matematika berbasis active learning yang telah dikembangkan peneliti memiliki dampak terhadap kemampuan berpikir kreatif siswa atau dengan kata lain, efektif untuk digunakan dalam memfasilitasi kemampuan berpikir kreatif matematika bagi siswa.

\section{REFERENSI}

Cahyo, N. A. (2013). Panduan Aplikasi Teori-Teori Belajar Mengajar Teraktual dan terpopuler. Yogyakarta: DIVA Press.

Hamzah, A. , dan Muhlisraini, (2014). Perencanaan dan Strategi Pembelajaran Matematika, Jakarta: PT Rajawali Pers.

Fauziyah, I. N. L. , Usodo, B. \& Ekana Ch. , H. (2013). Proses Berpikir Kreatif Siswa Kelas X dalam Memecahankan Masalah Geometri Berdasarkan Tahapan Wallas ditinjau dari Adversity Quotient (AQ) Siswa, Jurnal Pendidikan Matematika Solusi Vol. 1 No. 1

Majid, A. ,(2009). Perencanaan Pembelajaran, Bandung: PT Remaja Rosdakarya.

Mulyatiningsih, E. ,(2011). Metode Penelitian Terapan Bidang Pendidikan. Bandung: Alfabeta.

Pribadi, B. A. ,(2010). Model Desain Sistem Pembelajaran, Jakarta: Dian Rakyat.

Suryosubroto. (2009). Proses Belajar Mengajar di sekolah. Jakarta: Rineka Cipta.

Sanjaya, W. ,(2006). Strategi Pembelajaran Berorientasi Standar Proses Pendidikan. Jakarta: Kencana.

Sugiyono. (2013). Metode Penelitian Pendidikan. Bandung: Alfabeta.

Warsono. (2014). Pembelajaran Aktif. Bandung: PT. Remaja Rosdakarya.

Wena, M. (2011). Strategi Pembelajaran Inovatif Kontemporer. Jakarta: Bumi Aksara.

Slamet,Y. (2008). Pengantar Penelitian Kuantitatif, Surakarta: UNS Press. 